\title{
SUCCESSION RIGHT OF THE CHILD BORN OUT OF WEDLOCK: AN APPRAISAL OF THE NIGERIAN LAW ON LEGITIMIZATION AND THE ISLAMIC LAW
}

\author{
Jamiu Ridwanullah Kayode \\ Islamic and International Law Department, \\ Faculty of law, Lagos State University, Lagos state \\ ridone1424@gmail.com \\ 08059772563, 08138879937
}

\begin{abstract}
Succession is a common social challenge. Different people have different approach to it. Pluralism is a feature of Nigerian Legal system due to the presence of people of diverse culture, religion and language. Inheritance of a child born out of wedlock is especially knotty. The law had denied him the right to inherit from his putative father until 1979 when the Nigeria Constitution proscribed discrimination against any Nigerian on the basis of the circumstances of their birth. The same provision is preserved in the 1999 Constitution. The effect is that once the putative father acknowledges the child he is entitled to succeed to his father's estate after his demise. Shari'ah, the Islamic law, is another system of law in Nigeria which is applicable to the Muslims. Most Muslim jurists hold the opinion that a child born out of wedlock can only inherit from his mother. This opinion is not consensual though. A significant minority has held that the child can inherit from his biological father after acknowledgement. Views of the two schools of thought in this matter were examined in this paper. It was discovered that the opinion that the child born out of wedlock can inherit both parents after legitimation through acknowledgement is preponderant and in tandem with the provision of the Nigerian Constitution and natural justice.
\end{abstract}

Key words: Succession, legitimization, Shari’ah, constitution, wedlock 


\section{Introduction}

Succession involves the transmission of the rights and obligations of the deceased person in respect of his estate to his heirs and successors. ${ }^{1}$ Succession is either testate, when the deceased made a valid will before his demise, and intestate, when he leaves no valid will. Will is the legal expression of an individual's wishes about the disposition of his or her property after death. ${ }^{2}$ In English law which is also applicable in Nigeria, the testator has an unfettered right to share his estate in his will as he wishes, subject though to certain limitation. ${ }^{3}$ In Shari'ah - the Islamic law, will is referred to as Wasiyyah. In Shari' ah however a Muslim cannot, properly speaking, die intestate because there is a law relating to inheritance (and a law that he cannot vary) which becomes automatically applicable to his estate when he dies. ${ }^{4}$ Although both statutory wills and wasiyyah take effect after death, there are so many differences between both. Under statutory law, a testator can dispose of all his property by will but under Islamic law, he cannot dispose of more than a third of his estate by will. However, he may do so if his heirs consent to it. He cannot also bequeath to any of the persons who are by law his heirs. Again, he may do this subject to the consent of the other heirs. As a matter of fact, the various Wills laws (statutory will) do not apply to Muslims. ${ }^{5}$

\footnotetext{
${ }^{1}$ Olatoye, K.A, Inheritance in a Muslim Family: the Nigerian Experience, in A Digest on Islamic Law and Jurisprudence in Nigeria. (Edo: NAMLAS Publication, 2003) 57. See also: Inheritance, ‘https://www.britannica.com/topic/inheritance-law> Accessed 15 September 2020.
}

${ }^{2}$ Black's Law Dictionary, [9 $9^{\text {th }}$ edn.], p. 1735, Bryan A. Garner, editor in chief, 2009.

${ }^{3}$ S. 1 of the Wills Law of Lagos State with similar provisions in the old Western Region reads as follows:- "It shall be lawful for every person to bequeath or dispose of by his Will executed in accordance with the provisions of this Law, all property to which he is entitled, either in law or in equity, or at the time of his death - Provided that the provision of this Law shall not apply to any property which the Testator had no power to dispose of by Will or otherwise under customary law to which he is subject". See also section 2 of the Act.

${ }^{4}$ Ambali, M.A., The practice of Muslim family law in Nigeria, $\left(3^{\text {rd }}\right.$ edn. Lagos: Princeton publishing company, 2014) 2.

${ }^{5}$ Section 4 (1) of the Wills Law of Kwara State which states thus:

It shall be lawful for every person to bequeath or dispose of by his will executed in accordance with the provisions of this law, all property to which he is entitled, either in law or in equity, at the time of his death; Provided that the provisions of this law shall not apply to the will of a person who immediately before his death was subject to Islamic Law. ${ }^{5}$ 
Generally, the law, culture and public policy have it that the estate of the praepositus, whether by will or Inheritance, devolves to his heirs who are primarily the spouse and the children. ${ }^{6}$ Are children born out of wedlock eligible to inherit from their putative fathers? This is an issue that the law has viewed from different perspectives. This write-up aims at appraising different legislations on the matter especially the Nigerian constitution and the Shari'ah.

\subsection{What is Shari'ah?}

Shari'ah literally means the path that leads to the spring where drinking water is fetched. ${ }^{7}$ Technically, Shari'ah has been variously defined by Muslim Jurists but the purport is as Ambali puts it, 'Shari'ah is a legal system revealed as part and parcel of Islamic religion and put in practice by the Prophet of Islam. ${ }^{8}$

The scope and content of the Islamic law, as observed by Paramole, ${ }^{9}$ includes: practical devotion (Ibadaat), personal matters such as marriage, divorce, inheritance, wills (ahwalushakhsiyyah), contracts, sales, (mu'amalat), crimes and punishments ('uqubat), state laws, the courts (ahkamu-sultaniyyah, national and international relations (alaqatu-d-dawliyyah) and morality (tahdhibu/akhlaq).

The sources of Shari'ah or the Islamic law are divisible into chief and subsidiary sources. ${ }^{10}$ The Qur'an (the words of Allah) and the Sunnah (traditions of the Prophet Muhammad), referred to as An-Nass, i.e., command, constitute the two main sources of Islamic law with the Qur'an taking priority over the Sunnah. ${ }^{11}$ Subsidiary sources include Ijma (unanimous consensus of Muslim jurists), Qiyas (juristic opinion based on analogical reasoning), and 'Urf (customary practices which conform to the principles of Shari'ah). ${ }^{12}$ Doi, however, divided the sources of Islamic law into Textual sources (which are the Qur'an, Sunnah and Ijma) and intellectual sources among which are the juristic principles based on Qiyas, Masalih Mursalah (public interest), Istis-hab (legal presumption), 'Urf (custom) and Saddadh-dhara'i

\footnotetext{
${ }^{6}$ This perhaps informs the decision of the law-makers in the section 2 of the Lagos Wills law which reads:

"Notwithstanding the provision of Section 1 of this Law where a person dies and is survived by any of the following persons:

(a) the wife or wives or husband of the deceased; and

(b) a child or children of the deceased.

That person or those persons may apply to the Court for an order on the ground that the disposition of the deceased estate effected by his Will is not such to make reasonable financial provision for the Applicant.

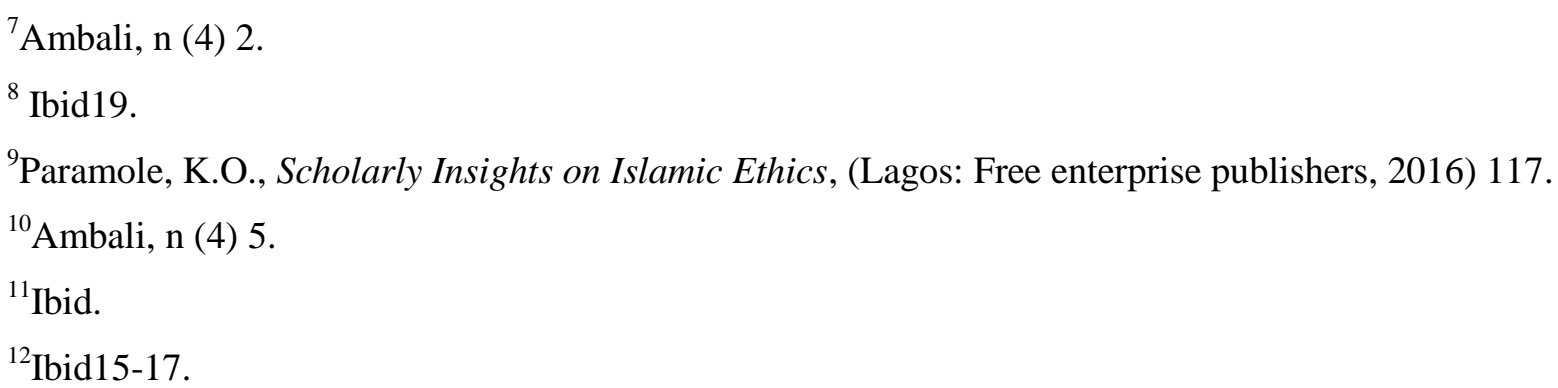


(blocking the means of access to crime). ${ }^{13}$ Shari'ah, the Islamic law, is one of the world's legal systems. Islamic law is an all-embracing legal system that regulates and guides the life and conduct of Muslims concerning their rights and duties. The purpose of the law is to promote the welfare of the people both individually and collectively and its basic principles are justice, equality, liberty and fraternity. ${ }^{14}$

\subsection{Differences between Shari'ah and Common Law}

Shari'ah is a legal system like the English law. It has its own substantive and procedural laws as well as legal maxims and principles. ${ }^{15}$ The major difference between Shari'ah and English law is that the former is fundamentally divine ${ }^{16}$, i.e., based on revelation from Allah, while the latter emanated from people's practices, statutes and case laws. The former is God-given while the latter is man-made. Dr Perron, commenting on Islamic law, said:

"For here it has been neither the nation nor the people which has made the law, it is the law which has made and moulded the nation and the people. Both the outer form and the inner spirit bear the impress of one word religion in Islam, there is but one law... and it is the religious laws, signified in the word Shariah. In other words it is the only supreme law; for it emanates from God, who decreed its main basis in the Qur'an.",17

English common law derives from different sources and evolves in different times before it assumes its current status. It is the codification of laws 'common' to the whole of England and Wales, which were developed by judges, decisions of king or Lord Chancellor in Equity meant to mitigate the harshness of common law, statutes promulgated by the Parliament, canon law of the Ecclesiastical courts and law of merchants, applied initially to adjudicate commercial cases involving domestic and foreign traders. ${ }^{18}$ These sources and origins of law as today fine-tuned and modified are together referred to as the English legal system or Common law. All Nigerian local legislations largely derive from and reflect the Common law.

After listing laws applicable in Nigeria on Trust, Banire observed "These legislations govern the law of trust in Nigeria. Many of them are based on similar legislations in England. ${ }^{19}$ Hon.

\footnotetext{
${ }^{13}$ I. Doi, Abdar-Rahman, Shari'ah: Islamic Law, (2 $2^{\text {nd }}$ edn. London: Ta-Ha PublishersLtd., 2008)98130.

${ }^{14}$ Gurin, A. An introduction to Islamic law of Succesion, ( $2^{\text {nd }}$ edn., Lagos: Malthouse law books, 2015) 1 .

${ }^{15}$ Dodo Mohammed, L.M., Islamic law and procedure, a digest on Islamic law and jurisprudence in Nigeria, (Edo: Darun-Nur NAMLAS publication 2003) 15.

${ }^{16}$ Adamu, U.F., 'Shari'ah between Acceptance and Rejection', ( $1^{\text {st }}$ edn. Ibadan: Caligata, 2001)14.

${ }^{17}$ Olukolu, Y., Customary Versus Islamic Laws of Marriage: The Unsettled Matter in the Nigerian Family Law, the journal of private and property law, (JPPL, University of Lagos, 2013) 96.

${ }^{18}$ Ibid38-40.

${ }^{19}$ Banire, M., The Nigerian Law of Trusts, (Lagos: Excel Publications, 2002)10.
} 
Justice Wali, JSC (as he then was) of the Supreme Court in Alhajilla Alkamawa v. Alhaji Hassan Bello and Alhaji Malami Yaro in his lead judgement, observed inter alia,

"Islamic law is not the same as customary law as it does not belong to any particular tribe. It is a complete system of universal law, more certain and permanent and more universal than the English Common Law."20

\subsection{Applicability of Shari'ah in Nigeria}

By virtue of the provision of the Nigerian constitution, states have powers to Sharia Court of Appeal. ${ }^{21}$ Shari'ah courts are empowered to administer the Muslim personal law involving civil proceedings. ${ }^{22}$ Section 262 (2) (c) provides:

(2) For the purpose of subsection (1) of this section, the Sharia Court of Appeal shall be competent to decide,

(c) any question of Islamic personal law regarding a Wakf, gift, will or succession where the endower, donor, testator or deceased person is a Muslim.

\subsection{Legitimacy of a Child}

Legitimacy in layman's language means the status acquired by a person who is born to parents who are married to one another at the time of the birth. Legitimization means that a person who has not been born to married parents acquires the status of legitimacy as a result of some act. ${ }^{23}$ Legality of marriage affects many crucial life issues involving rights and privileges, will, inheritance, divorce, child custody, guardianship, annuity and insurance, among others. What constitutes legal and valid marriage is relative though. Marriage under the Nigerian Marriage $\mathrm{Act}^{24}$ does not apply to Muslims. Islamic family law provides certain regulations and conditions for the validity of marriage which are not necessarily considered under the Act. ${ }^{25}$ This includes consent of the parties to it, Ijab and Qabul (offer and acceptance) or formal consent of the guardian of the woman, witnesses. Dowry is also a

\footnotetext{
${ }^{20}$ Oseni, U.A, Shari'ah, anti-Shari'ah Muslims and the Nigerian Legal System, in Essays in memory of late HajiaFaoziyyahKehinde Ali, Al-Maslaha, Journal of Law and Religion. (Ilorin: NAMLAS publications 2006) 145.

${ }^{21}$ See Sections 275 to 279 of the Constitution of the Federal Republic of Nigeria, 1999 (as amended).

${ }^{22}$ On August 8, 1999 however, Zamfara State government reversed the trend when it enacted the Sharia Courts (Administration of Justice and Certain Consequential Changes) Law. The Law empowered the grassroots Sharia Courts to apply Islamic Law in all family, civil and criminal matters and appeals from them go to the Sharia Courts of Appeal. The Zamfara initiative was followed by a number of states with predominant Muslim populations such as Sokoto, Niger, Kebbi, Katsina, Borno and Yobe. Other sister states with modification are Kaduna and Taraba. See Ambali, n (7) 30.

${ }^{23}$ Legitimization Law and Legal Definition, available at:

https://definitions.uslegal.com/l/legitimization/ Accessed 7 January 2021.

${ }^{24}$ Also referred to as court wedding or white wedding or registry marriage.

${ }^{25}$ See Sections 39 and 46.
} 
condition of marriage but not a condition for the validity. ${ }^{26}$ Bigamy is an offence in the Marriage Act while the Shari'ah permits marriage to the maximum of four wives. Allah says,

"If you fear you cannot act fairly towards the orphans- then marry the women you like - two, or three, or four. But if you fear you will not be fair, then one, or what you already have as slave-girls. That makes it more likely that you avoid bias,"27

There is unlimited polygyny under the customary law and practices which is contrary to Islamic law.

Schools of Islamic jurisprudence also differ as regards the requirement of a guardian as a condition for the validity of marriage. Majority of the schools including the Malikis, Shafi's and Hanbalis consider guardianship a condition, while the Hanafis do not consider it a condition for a mature woman. ${ }^{28}$ When a marriage is valid ${ }^{29}$ however, children born during the subsistence of the marriage are legitimate. Succession rights are generally established for them, among others. The bone of contention is the inheritance right of a child born out of wedlock.

\subsection{Legitimization of a Child}

Legitimatization or establishment of paternity and its rights for a putative father who acknowledges a child born out of wedlock is a contentious matter. Legitimatization means that a person who has not been born to married parents acquires the status of legitimacy as a result of acknowledgement by the putative father. ${ }^{30}$ In some legal systems, legitimization is a way of establishing legitimacy for a child and hence, succession right while this is against many cultures and legal systems.

\subsection{Legitimization in the Nigerian Law}

Nigeria's legal pluralism is reflective of her plurality in ethnicity, history and religion. The plural court system is meant to effectively and satisfactorily administer justice to people of different inclinations and leanings. Hence, there are the customary and Shari'ah courts

\footnotetext{
${ }^{26}$ Abu bakr Jabir Al-Jazairy, Minhaj Al-Muslim, (1 ${ }^{\text {st }}$ edn. Riyadh:Darussalam, 2001) 2(321-326).

${ }^{27}$ Surah al-Nisa, Qur'an Chapter 4 verse 3.

${ }^{28}$ Ibn Rushd, The Distinguished Jurist's Primer (Bidayat al-Mujtahid waNihayat alMuqtasid),(1 ${ }^{\text {st }}$ edn. Lebanon: Garnet Publishing Limited, 1996) vol. 2(9).
}

${ }^{29}$ Ibn Taymiyya, one of the leading Muslim scholars observes, ', The Muslims have agreed that if a Muslim consummates a marriage with his wife in a marriage which he believes to be valid, then his child from that marriage bears his name and they inherit from each other, according to the consensus of the Muslims...the confirmation of family lineage does not require the validity of marriage; rather, the child belongs to the owner of the bed, as the prophet said, 'the child belongs to the owner of the bed and the stone is for the adulterer."

${ }^{30}$ Paul OkhaideItua, Legitimacy, legitimation and succession in Nigeria: An appraisal of Section 42(2) of the constitution of the Federal Republic of Nigeria 1999 as amended on the rights of inheritance. Available athttps://academicjournals.org/article/article1379860996_Itua.pdf. Accessed on 29 November 2019. 
alongside the common courts which are largely styled after the English system. Approach to inheritance of child born out of wedlock depends on culture and law one is subject to before a stand was taken in the 1979 Constitution.

At common law, an illegitimate child had no right whatsoever with regard to his parent. He is described as filius nullius. ${ }^{31}$ The illegitimate child was a stranger in law not only to his father but also to his mother and all other relatives. He thus, has no legal right to succeed to their property, to receive maintenance or other benefits deriving from the status of parent and child." 32

In Adeyemi v. Bamidele, ${ }^{33}$ the Nigerian Supreme Court held that "...Legitimacy in England is a different concept to legitimacy in Nigeria." Thus, the Legitimacy Ordinance of 1929 has modified this common law position. Thus, by Section 10 of the Ordinance, where the mother of an illegitimate child dies intestate after 17 October 1929, leaving real or personal property, but not survived by any legitimate child, the illegitimate child or if he is dead, his issue, is entitled to take any interest in the estate to which he or his issue would have been entitled to if he had been born legitimate. Also, where an illegitimate person who has not been legitimated dies intestate in respect of all or any of his real or personal property, his mother, if surviving shall be entitled to take any interest in his estate to which she would have been entitled if the child had been born legitimate and she had been the only surviving parent. It has been argued that this ordinance provided partial remedy to the problem created by the common law rules concerning illegitimacy. ${ }^{34}$ Legitimacy Act of 1929 considered subsequent marriage of the parents of the illegitimate child as a means of legitimation. ${ }^{35}$

Under customary laws however, a child though born out of wedlock can be legitimated by acts of acknowledgement by his putative father. The legal effect of acknowledgement was aptly described by Cole, $\mathrm{J}$ in Taylor v. Taylor" when he held that "the acknowledgement of paternity by the father ipso facto legitimatizes the children and there could not for the purpose of succession be different degrees of legitimacy".

Section 42 (2) of the Constitution of the Federal Republic of Nigeria, 1999 (as amended) provides, thus:

\section{No citizen of Nigeria shall be subjected to any disability or deprivation merely by reason of the circumstances of his birth.}

This provision emphasizes an aspect of the fundamental human rights enjoyed by everyone. No one is to blame for an offence they did not commit. Circumstances of birth, being born

\footnotetext{
${ }^{31}$ Ibid.

${ }^{32}$ Ibid.

${ }^{33}$ Adeyemi v. Bamidele [1968] 1 All N.L.R. 31 at p.37.

34 Paul (n30).

${ }^{35}$ ibid.

${ }^{36}$ Taylor v. Taylor (1960) L.L.R. 286.
} 
out of wedlock inclusive, should not be a ground to discriminate against a person. He is covered by alibi.

This provision of Section 42 (2) of the 1999 Constitution $^{37}$ is really a revolution against what obtained in Nigeria at law and culture with regard to the consequences of illegitimacy on the right to inheritance.

In Dr. T.E.A. Salubi v. Mrs. Benedicta Nwariakwu and $\mathrm{Ors}^{38}$, the deceased Chief T.E.A. Salubi was married to Mrs. Angela Salubi under the Marriage Act in 1939. They had two children namely the appellant, Dr. T.E.A. Salubi and the first respondent Mrs. Benedicta Nwariakwu. The deceased later had two other children out of wedlock from two women. After the death of Chief Salubi in 1982, his first son, the appellant in this case and his mother were granted letter of administration to administer the estate in 1985. Later the appellant became the sole administrator as a result of their mother's illness and old age. The first respondent being dissatisfied with the manner in which the appellant was handling the affairs of the estate, instituted an action at the High Court seeking to set aside the letter of administration, and an order that the probate registrar should effect the distribution of the estate of the deceased to all beneficiaries in accordance with the marriage ordinance applicable to the deceased. The trial court set aside the letter of administration as sought and also ordered that the Administrator-General should distribute the estate between the two children of the statutory marriage. It further held that two children born out of wedlock, being illegitimate were not entitled to share in the distribution of the estate. The appellant appealed to the Court of Appeal. On the exclusion of the other two children on the ground that they were illegitimate children, the Court of Appeal rejected the argument and held that the court cannot shut its eyes to the specific provision of Section 39(2) of the 1979 Constitution, and to hold that the two children born out of wedlock in the instant case were not entitled to benefit from the Estate of their acknowledged father who had died intestate amounted to subjecting them to disability or deprivation merely by reason of the circumstance of their born out of wedlock, which was exactly what Section 39(2) of the Constitution was aimed at preventing. Commenting further Ige, J.C.A., observed as follows:

"Under our law and the provisions of the Constitution of the Federal Republic of Nigeria 1979, they are lawful children and entitled as beneficiaries under the estate of their later father... the decision in Cole v Akinyele... is no longer the law."

On a further appeal to the Supreme Court, the Supreme Court held that

"the court below was right in holding that the trial court had jurisdiction to entertain the claim before it and that the two issues born out of wedlock are entitled in equal shares with the two other issues of the marriage of the deceased and the widow."

From the above judicial opinion, it is clear that the law now recognizes as legitimate children, children born out of lawful wedlock provided their paternity was acknowledged by their putative father irrespective of the form of marriage contracted by the father.

\footnotetext{
${ }^{37}$ Which is a repeat of similar provision at Section 39 of the 1979 Constitution.

${ }^{38}$ (2003) 7 NWLR (Pt. 819) 426.
} 
The provision of Section 42(2) of the 1999 Constitution has thus effectively eliminated the status of illegitimacy in Nigeria. Once a child has been acknowledged by his putative father, he is entitled to equal share of his estate with the children born in lawful wedlock. The effect of this provision is that there is no legal distinction between children born in a lawful wedlock and children born out of wedlock. This is because the sectionspecifically precludes discrimination against a child on the basis that he/she was born outside wedlock. ${ }^{39}$

Also, in the recent case of Mgbodu v. Mgbodu ${ }^{40}$ the Court of Appeal held that a child born out of wedlock must not be prevented from partaking in the sharing of his deceased father's estate. His Lordship, Bolaji-Yusuff, JCA at page 439 paragraphs D-F held thus:

It has long been established that in this land, Nigeria, once a father acknowledges the paternity of a child whether born in or out of wedlock, the child is regarded as a legitimate child and is entitled to share in the estate of his/her father...This custom has now received a constitutional approval first through section 39 of the constitution of the Federal Republic of Nigeria, 1979 and now through section 42 of the 1999 Constitution (as amended) which provides that no citizen of Nigeria shall be subjected to any disability or deprivation merely by reason of the circumstances of his birth.

The implication of the foregoing is that the mere fact that a child was born out of wedlock will not be an impediment to the child getting an equal share of his/her deceased parent's properties with the children born in a legitimate wedlock.

\subsection{Inheritance right of a child born out of wedlock in Islamic law (Sharia)}

Inheritance of a child born out of wedlock is consequent upon the establishment of paternity. There is a consensus amongst Muslim jurists that marriage is the primary means of determining legitimacy of children and paternity. ${ }^{41}$ Legitimatization or establishment of paternity and its rights for a putative father who acknowledges a child born out of wedlock is a contentious matter. The following is credited to Prophet Muhammad in the Hadeeth: "The child belongs to the husband while the adulterer gets stones ${ }^{42}$ or stoned ${ }^{43}$." The bone of contention is the inheritance right of an illegitimate child who has been acknowledged by the biological father.

\footnotetext{
39 "Intestate Succession in Nigeria: What is the Status of Children Born out of Wedlock? Available at:https://www.legalnaija.com/2015/09/intestate-succession-in-nigeria-what-is.html. Accessed on 20th October 2019.

${ }^{40}$ (2015) 12 NWLR (Pt. 1474) 415

${ }^{41}$ Another way to establish legitimacy in Shari'ah is slavery. It is permissible to have conjugal relations with rightly possessed slave-girls when that was the convention. Allah says, "And those who guard their chastity. Except from their spouses or those (slave-girls) living under their control, for then they are free of blame. But whoever seeks to go beyond that - these are the transgressors," Qur'an 70/29-31.

42 i.e., nothing

${ }^{43}$ Punishment for adultery under Islamic law is stoning to death if the convict is in a marriage.
} 
Acknowledgement of paternity by a putative father in the absence of marriage of the mother is a contentious matter in Islamic jurisprudence. Sabiq ${ }^{44}$ though reported a consensus that a child born out of wedlock is barred from inheriting his putative/biological father. His assertion is however, too blanket.He does not clarify a situation when the putative father acknowledges the child, which is a matter about which Muslim jurists have two opinions. ${ }^{45}$ Majority of the Sunni schools of thought proscribed the paternity and its corollary even if the putative father acknowledges him thereafter. ${ }^{46}$

Ambali $^{47}$, lending credence to this view, observes that a child born out of wedlock is not qualified to inherit from the estate of the partner of his/her mother in the act of Zinaand the man too is barred from sharing in the estate of the product of his illegal association, Zina, with a woman. However, the mother and the child are free to inherit each other. ${ }^{48}$ Since biological fathers are not legal fathers and biological children are distinguishable from legally produced children, the law has no provision for the biological but not legal children in its law of succession. However, such biological fathers are free to treat children as non-heir beneficiaries of Wasiyyah. In their lifetime, they are equally free to extend their hand of kindness to such person as blood or non-blood related person. ${ }^{49}$

But an eminent minority among the Muslim jurists affirms the paternity after acknowledgement, and thereby the inheritance between them. This is the view supported by Imam Abu Hanifah, Ibn Taymiyya and Ishaq bin Rahuwayh, among others. The weight of the two opinions will be considered.

That every child must have a mother is a general knowledge, for Allah says; "None can be their mother except those who gave them birth..." (Q58/2) But for its socio-economic significance, Islam goes further to emphasize that every child must have a father to whom he will be legally related and on whose shoulder his maintenance and upbringing rest. ${ }^{50} \mathrm{~A}$ man on whom the paternity of a child revolves is one upon whom the maintenance of a child (male or female) legally revolves. The child bears his name. They can inherit each other and has full right of a child unless such is vitiated by other legal reason.

\subsubsection{Arguments of those who bar a child born out of wedlock from inheriting his putative father after acknowledgement}

The following arguments have been adduced by scholars who proscribe inheritance between the putative father who acknowledges paternity and the child born out of wedlock.

\footnotetext{
${ }^{44}$ Sabiq S., Fiqh Sunnah, (20 $0^{\text {th }}$ edn., Cairo: Darul Fat-h, 2015) 4(252).

${ }^{45}$ Kamal S., Saheehfiqh al-Sunnah, (Cairo: Dar al Tawfiqiyyah, 2010) 3(409).

${ }^{46}$ Sabiq, n(33), Abdulrashid Y., and OkohE.E.,Succession under Islamic Law, (Lagos: Malthouse press Limited, 2011) 91.

${ }^{47}$ Ambali, n(4) at 344.

48 Ibid.

49 Ibid.

${ }^{50}$ The case of Prophet 'Isa (Jesus)-alayhis-salam is not meant here for that was a miraculous design of Allah the Wise; nor is that of Adam and Hawa -our progenitors- meant.
} 
i. The Hadith of the Prophet that "The child belongs to the owner of the bed (i.e., a legal husband) while stone is for the adulterer."

ii. The statement also attributed to the Prophet that "If a man commits fornication with a free woman or a slave woman, the child is the product of fornication, he neither inherits nor may anyone inherit from him"

iii. Hadeeth of Lian where the child is attributed to his mother and denied paternity of the partner.

\subsubsection{Arguments of those who support inheritance of an illegitimate child from the putative father}

Supporters of this position argue that:

i. The Hadith that attributes the child to the husband deals with a case when there is a dispute regarding paternity of a child between a legal husband of a woman and a putative father. The case being considered here is when there is no subsisting marriage or husband. This is well pronounced in an incident that occurred during the lifetime of the Prophet Muhammad. Aisha narrated that Sa'd ibn Abi waqqaas and Abdu ibn Zam'a quarrelled over a boy. Sa'd said, O Messenger of Allah, this boy is the son of my brother (Utba ibn Abi waqqaas) who took a promise from me that I would take him as he was his son. Look at him and see whom he resembles!" Abdu ibn Zam'a said, "O Messenger of Allah, this is my brother and was born on my father's bed from his slave girl." The Prophet cast a look at the boy and found definite resemblance to Utbah and then said, 'the boy is for you $\mathrm{O}$ Abdu ibn Zam'a. The child goes to the owner of the bed (i.e., the husband; who legally possesses the sexual right to a woman), and the adulterer gets nothing but stones (i.e. disappointment and deprivation, or to be stoned to death when proved guilty and where Shari'ah is applied). Therefore, nobody can claim paternity of a child while the legal father (or the husband) affirms the same.

ii. The second Hadeeth is not authentic according the verdict of many Hadeeth experts.

iii. Hadeeth on Lian also refers to a particular case where the husband denies paternity of the child. This happens when a man denies the paternity of his wife's pregnancy or child and they end up swearing and cursing themselves as prescribed by Allah in the Qur'an (24: 6 - 9). "And for those who accuse their wives, but have no witnesses except themselves, let the testimony of one of them be four testimonies (i.e. testifies four times) by Allah that he is one of those who speak the truth. And the fifth (testimony) (should be) the invoking of the Curse of Allah on him if he be of those who tell a lie (against her). But it shall avert the punishment (of stoning to death) from her, if she bears witness four times by Allah, that he (her husband) is telling a lie. And the fifth (testimony) should be that the Wrath of Allah be upon her if he (her husband) speaks the truth." The child that results will inherit from his mother only. ${ }^{51} \mathrm{~A}$ man who disowns the paternity of a pregnancy or child through the stipulated process of Lian shall not inherit from the woman (carrying the disowned pregnancy) if he dies, nor will she too inherit him. The child too cannot inherit from the man who has disowned his paternity and the man

\footnotetext{
${ }^{51}$ Abdulrashid and Okoh, n (43).
} 
too cannot inherit from the child. However, the child and the mother are allowed to inherit each other. ${ }^{52}$

\subsection{The preponderant opinion}

There are four basic principles in Islamic bioethics and law by which paternity may be established. ${ }^{53}$ (1) There must be a valid marriage contract between the mother and father of the child. Jurists consider that the minimum duration from the existence of a valid marriage contract to the birth of the child is 6 months. (2) Attribution is based on the principle that "the child belongs to the bed (where he or she was born)", referred to as al- waladli'l- firash-in other words, to the apparent father. (3) Acknowledgement (iqrar) by a husband that a child born to his wife is his, even if the child's genetic paternity may be in doubt.(4) In addition to the above, a man can claim parenthood and paternity if he is the genetic parent of the child. ${ }^{54}$

Egyptian Fatwa Council in December 20, 1979 stipulated certain conditions to be met in acknowledgement (Iqrarbil-nasab). ${ }^{55}$ These are:

a. That the child has no established parentage

b. That it is logical and practical that the child can naturally be borne by the claimant

c. That the child confirms the paternity if he is discerning. The first two conditions suffice if the child has not attained the age of discretion.

The council reiterated the Sharia position on the prohibition of legal adoption. ${ }^{56}$

During the time of Umar, children born out of wedlock by female slaves were ascribed to those who acknowledged their paternity. So in the case of a child who was conceived illegitimately the parents of such child may be punished for Zinaif found guilty, but the paternity goes to the biological father who acknowledges him as motherhood is naturally for

\footnotetext{
${ }^{52}$ The Prophet is reported to have said, "A woman succeeds to inheritance of three: her manumitted slave, her foundling and her child from Lian." Recorded by Abu Daud (2906) and Tirmidhi (2116). See Kamal, n (34) 410.

${ }^{53}$ Kabir M. and Banuaz-Zubair, 'Who is a parent? Parenthood in Islamic ethics'. Available at: https://www.ncbi.nlm.nih.gov/pmc/articles/PMC2652801/ accessed on 09 December 2019.

${ }^{54}$ The Noble Qur'an 4:23, in relating those to whom marriage is prohibited to man, clearly points to the genetic link between a father and son when it says, "Prohibited to you for marriage are ... those who have been wives of your sons proceeding from your loins ..." This is to distinguish genetic sons, who proceed from the loins, from adopted or culturally attributed sons, who have no such genetic link with the "father" - a clear indication that it is genetics that link a father to his child.

${ }^{55}$ https://fatwa.islamonline.net/2394

${ }^{56}$ Allah says, "Allah did not place two hearts inside any man's body. Nor did He make your wives whom you equate with your mothers, your actual mothers. Nor did He make your adopted sons, your actual sons. These are your words coming out of your mouths. Allah speaks the truth, and guides to the path. Call them after their father; that is more equitable with Allah. But if you do not know their fathers, then your brethren in faith and your friends. There is no blame on you if you err therein, barring what your hearts pre-meditates. Allah is Forgiving and Merciful." Q33/3-4
} 
the woman with whom the Zinawas committed. The same ruling applies when the union was later ratified by one whose consent lends validity to the marriage. The child should not be denied paternity and its rights because of the offence he was innocent of.

Ibn Qudaamah narrated from Abu Haneefah. He said: “"Ali ibn 'Aasim narrated that Abu Haneefah said: If a man commits Zina with a woman and she gets pregnant from him, I do not see anything wrong with him marrying her even though she is pregnant, so as to conceal her ( $\sin$ ), and the child will be his child." (al-Mughni, 9/122).

The following Hadeeth may be arguably used to buttress some points above.

Abu Hurayra narrated: the messenger of Allah said, "None spoke in the cradle but three; one was Jesus, the second was: 'There was an Israeli man called Jurayj, while he was praying, his mother came and called him, but he did not respond to her call. He said (to himself) whether he should continue the prayer or to reply to his mother. He went on praying, and did not answer her. She came to him the second time and called him... and she said (angrily), 0 Allah, do not let him die until he sees the faces of prostitutes (i.e. to be tempted by them).

Jurayj used to live in a hermitage. A woman said that she would entice Jurayj. So she went to him and presented herself (for an evil act) to seduce him but he refused. She then went to a shepherd and allowed him to commit an illegal sexual intercourse with her, and later she gave birth to a boy. She alleged that the baby was from Jurayj. The people went to Jurayj and dismantled his hermitage, pulled him out of it and abused him. He performed ablution and offered the prayer, then he went to the baby and asked him, o baby, who is your father? The baby replied that his father was the shepherd. The people after hearing this said that they would rebuild for him a hermitage of gold but Jurayj asked them to make it of mud only..." Bukhari 2482 and Muslim 2550

\section{Fatawa $^{57}$ on legitimization}

A reliable Fatawa source was quoted below concerning this issue. ${ }^{58}$

I'm an illegitimate child. I was conceived before my mother became Muslim. She became Muslim a few days before my birth. My parents married when I was 10 months old. My parents got divorced 2 years ago, after I disclosed sexual abuse by him. I have used my father's name since I was born and he has always accepted paternity of me. Do I need to change my name to my mother's name? I am 14-year-old and have five siblings, all with my father's name. I read the answers on this site and all seemed to say that I should, but one answer by Shaykh 'Abd-Allah ibn Jibreen seemed to say the opposite. (Question Reference Number 5967) He stated that if the father accepts paternity, it is permissible to retain his name. Please clarify this issue for me.

\section{Answer}

\footnotetext{
${ }^{57}$ Official religious verdict

${ }^{58}$ https://islamqa.info/en/answers/33591/an-illegitimate-daughter-is-asking-whose-daughter-am-i.
}

Accessed again 7 January 2021. 
Praise be to Allaah.

Firstly: we confirm that the illegitimate child has nothing to do with his parents' crime, and that he has all the same rights as any other Muslim, male or female. He must also fear Allaah so that he may become one of the people of Paradise with whom Allaah is pleased.

Secondly: the scholars differed as to whether or not the child may be attributed to his adulterous father, if the woman was not married.

What that means is: if the woman was married and had a child six months after being married, then the child should be attributed to the father, and he cannot deny the child unless he divorces his wife by means of li'aan. If a man claims that he committed zina with this woman and that this is his illegitimate child, no attention should be paid to him, according to scholarly consensus, because the Prophet (peace and blessings of Allaah be upon him) said, "The child is to be attributed to the husband and the adulterer deserves nothing." Narrated by al-Bukhaari, 2053; Muslim, 1457.

Ibn Qudaamah said: "The scholars were unanimously agreed that if a child is born to one man's wife, and another man claims it is his child, the child is not to be attributed to the latter. The difference of opinion arises when a child is born outside of marriage."

If the woman is not married, and she has a child as a result of zina, and the zaani (adulterer, man who committed zina) claims it is his child, should the child be attributed to him or not?

The majority of scholars are of the view that the child should not be attributed to him.

It was narrated from al-Hasan, Ibn Sireen, 'Urwah, al-Nakha'i, Ishaaq and Sulaymaan ibn Yassaar that the child should be attributed to him.

This was also the view favoured by Shaykh al-Islam Ibn Taymiyah (may Allaah have mercy on him). Ibn Qudaamah also narrated this view from Abu Haneefah. He said: "Ali ibn 'Aasim narrated that Abu Haneefah said: If a man commits zina with a woman and she gets pregnant from him, I do not see anything wrong with him marrying her even though she is pregnant, so as to conceal her (sin), and the child will be his child.” (al-Mughni, 9/122).

Ibn Muflih (may Allaah have mercy on him) said: Our shaykh [Ibn Taymiyah] favoured the view that a man may attribute to himself a child who is the result of zina with an unmarried woman. al-Furoo', 6/625

Ibn Qudaamah (may Allaah have mercy on him) said: The illegitimate child should not be attributed to the zaani according to the majority of scholars, but al-Hasan and Ibn Sireen said: he may be attributed to the zaani if the hadd punishment has been carried out on him, and he may inherit from him. Ibraaheem said: He may be attributed to him if the hadd punishment of flogging has been carried out, or if he becomes the owner of the woman with whom he had intercourse. Ishaaq said: He may be attributed to him, and he quoted something similar from 'Urwah and Sulaymaan ibn Yassaar.

Shaykh al-Islam (Ibn Taymiyah) said: There are also two views among the scholars concerning the zaani claiming the child as his if the woman is not married. The Prophet (peace and blessings of Allaah be upon him) said: "The child is to be attributed to the 
husband and the adulterer deserves nothing." So he said that the child belongs to the husband, not the zaani. But if the woman is not married then this hadeeth is not applicable. 'Umar attributed children born in the jaahiliyyah to their fathers, but this is not the place to discuss this issue in detail. Al-Fataawa al-Kubra, 3/178

\section{Conclusion}

The implication of the above is that in Islamic law, there is no verse of the Qur'an or authentic Hadeeth or Ijma that prohibits a child born out of wedlock from inheritance, provided that he is acknowledged by the putative father and the woman gave birth to the child when there is no subsistence of marriage between her and another man. The effect of this is that the view that the child born out of wedlock is entitled to inheritance of his father who acknowledges his paternity is stronger and preponderant. It is in tandem with natural justice and preserves the fundamental human right of the child. It is also the purport of the legitimization provision of the Nigerian constitution. Therefore, the legitimization law in Nigerian constitution is in consonance with the Shari'ah.

The above is not meant however to trivialise the offence of adultery or the danger of promiscuity, it is rather meant to view the matter from the legal lens in order to determine the legal consequences of its occurrence.

Allah says, “And do not come near adultery. It is immoral, and an evil way.”Q17/32

"The adulteress and the adulterer-whip each one of them a hundred lashes, and let no pity towards them overcome you regarding Allah's Law, if you believe in Allah and the Last Day. And let a group of believers witness their punishment."Q24/2

Ambali has rightly observed that: ${ }^{59}$

It is worthy to note that the difference between the reproduction of human beings and that of lower mammals is solemnization of marriage (Nikah). Human civilization will be destroyed, and men reduced to animals as soon as the recognized institution of marriage is done away with. Then the sacred essence of spouse relationship will be no more. Without respect for the regulations which govern marriage, there will be no human race at all. Rather, what we shall have is a race of brutes in human form. Worse than that is for a peer of same gender to contract marriage. It violates the form and regulations of Islamic mode of marriage designed by Allah for His believers, one of which is procreation process through the union of a couple of one man and one woman. It disrupts the ordinances of inheritance built on the Islamic cultural system of Islamic marriage.If there is no marriage, then there can be no family, no ties of kinship, no force uniting the different elements of humanity, and consequently, no civilization. It is through the family that humanity is held together, and civilization made possible. This can only be achieved if the laws governing the marriage are respected and followed.

${ }^{59}$ Ambali, n(7) 344. 


\section{REFERENCES}

\section{STATUTES AND CONSTITUTION}

Constitution of the Federal Republic of Nigeria, 1999 (as amended 2010)

Wills Law, CAP W2, Laws of Lagos State

Wills Law of Kwara State, CAP 168 Laws of Kwara State 1991

Administration of Estates law, CAP A3, Laws of Lagos State

\section{BOOKS}

- Abdulrashid Y., and Okoh E.E., Succession under Islamic Law, Lagos: Malthouse press Limited, (2011).

- Abu bakr Jabir Al-Jazairy, Minhaj Al-Muslim, (1 ${ }^{\text {st }}$ edn. Riyadh: Darussalam, 2001).

- Adamu, U.F., Shari'ah between Acceptance and Rejection, $1^{\text {st }}$ edition. Ibadan: Caligata, (2001).

- Ambali, M.A., The practice of Muslim family law in Nigeria, $3^{\text {rd }}$ ed. Lagos: Princeton publishing company, (2014).

- Banire, M., The Nigerian Law of Trusts, Lagos: Excel Publications. (2002).

- Black’s Law Dictionary, [9 $9^{\text {th }}$ ed.], p. 1735, Bryan A. Garner, editor in chief, 2009

- Dodo Mohammed, L.M., Islamic law and procedure, a digest on Islamic law and jurisprudence in Nigeria, Edo: Darun-Nur NAMLAS publication (2003).

- Gurin, A. An introduction to Islamic law of Succession, $2^{\text {nd }}$ edition, Lagos: Malthouse law books, (2015).

- Ibn Rushd, The Distinguished Jurist's Primer (Bidayat al-Mujtahid waNihayat alMuqtasid), $1^{\text {st }}$ edition, Lebanon: Garnet Publishing Limited, (1996).

- I. Doi, Abdar-Rahman, Shari'ah: Islamic Law, $2^{\text {nd }}$ ed. London: Ta-Ha PublishersLtd., (2008).

- Kamal S., Saheehfiqh al-Sunnah, Cairo: Dar al Tawfiqiyyah, 2010.

- Olukolu, Y., Customary Versus Islamic Laws of Marriage: The Unsettled Matter in the Nigerian Family Law, the journal of private and property law, (2013) JPPL, University of Lagos. 
- Oseni, U.A, Shari'ah, anti-Shari'ah Muslims and the Nigerian Legal System, in essays in memory of late HajiaFaoziyyah Kehinde Ali, Al-Maslaha, Journal of Law and Religion. Ilorin: NAMLAS publications (2006)

- Paramole, K.O., Scholarly Insights on Islamic Ethics, Lagos: Free enterprise publishers, (2016).

- Sabiq S., Fiqh Sunnah, 20 ${ }^{\text {th }}$ ed., Cairo: Darul Fat-h, (2015).

\section{ONLINE REFERENCES}

- Paul OkhaideItua, Legitimacy, legitimation and succession in Nigeria: An appraisal of Section 42(2) of the constitution of theFederal Republic of Nigeria 1999 as amended on the rights of inheritance. Available athttps://academicjournals.org/article/article1379860996_Itua.pdf.

- "Intestate Succession in Nigeria: What is the Status of Children Born out of Wedlock? Available at:https://www.legalnaija.com/2015/09/intestate-successionin-nigeria-what-is.html.

- Kabir M. and Banuaz-Zubair, 'Who is a parent? Parenthood in Islamic ethics'. Available athttps://www.ncbi.nlm.nih.gov/pmc/articles/PMC2652801/ https://islamqa.info/en/answers/33591/an-illegitimate-daughter-is-asking-whose$\underline{\text { daughter-am-i }}$

- https://fatwa.islamonline.net/2394 